\title{
Teaching Consolidations Accounting: An Approach To Easing The Challenge
}

Elizabeth A. Murphy, DePaul University, USA

Mark A. McCarthy, DePaul University, USA

\begin{abstract}
Teaching and learning accounting for consolidations is a challenging endeavor. Students not only need to understand the conceptual underpinnings of the accounting requirements for consolidations, but also must master the complex accounting needed to prepare consolidated financial statements. To add to the challenge, the consolidation process is dependent on how the parent company accounts for the investment on its parent company ledgers. Parent company ledgers either use the cost method or some variation of the equity method to account for investments to be consolidated. The variety in those accounting approaches used by parent companies is comparable to the variety of approaches to teach consolidations that are presented in advanced accounting textbooks, as documented by Luehlfing (1995). Luehlfing outlines the parent company accounting methods that are presumed to be used to teach consolidation accounting in each of the existing U.S. advanced accounting texts, noting that authors promote one method over others. Luehlfing suggests that students should be provided with a comparison of the parent company entries under the cost method and each adaptation of the equity method so that they can obtain a better understanding of the differences in the consolidation worksheet elimination/reclassification entries. Rather than having students learn different consolidation worksheet entries as a result of different recording methods used by the parent for an investment requiring consolidation, an approach can be adopted so that students only need to learn one set of consolidation worksheet entries to develop consolidated financial statements. In addition, a method of analyzing the parent's investment account can be used to not only help understand the conceptual issues associated with consolidation accounting, but also greatly facilitate the mechanics of preparing the consolidation worksheet entries.
\end{abstract}

Keywords: consolidations, equity method

\section{INTRODUCTION}

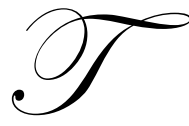

eaching consolidations accounting is a challenge primarily due to the complexity of the accounting issues and the analytical skills required by students to understand the underlying concepts. Prior authors have attempted to address the complexity by recommending approaches to teaching various facets of consolidation accounting.

Spiller (1962) recommends teaching consolidated income statements separately from the rest of the consolidated statements to improve student understanding. Perry (1963) offered recommendations for intercompany worksheet entries under the relatively new accounting alternatives under ARB 51. Because Keister (1976) believed that intercompany bond transactions were significantly more difficult and different than intercompany inventory and fixed asset transactions, he offered an approach for teaching intercompany bond transactions that utilized the entries recorded on the parent and subsidiary's books. O'Connor, Rapaccioli, and Williams (1996) believe that the topic of consolidations is ideal for internationalizing the accounting curriculum. Scofield (1996) suggests that Alcoa's financial statements should be used to teach all of the potential consolidation accounting alternatives under consideration in the mid-1990's in the U.S. Chasteen (2005) offers recommendations for consolidation of variable interest entities and makes comparisons to consolidation of subsidiaries. Nurnberg \& Sweeney (2007) believe that both non-GAAP and GAAP methods of consolidations should be learned in order to better understand the 
conceptual underpinnings of the alternatives and the strengths and weaknesses of the method ultimately chosen as GAAP. James (2008) used consolidations and other accounting topics to evaluate student skills in identifying errors on the financial statements and in the footnote disclosures. All of these authors examined consolidations from different perspectives with the goal of improving student learning.

Luehlfing (1995) identified the consolidations accounting approaches that U.S. advanced accounting authors incorporated into their textbooks. Luehlfing determined that the textbook authors typically identified a primary investment accounting method assumed for the parent for their consolidations presentation, but many also presented the consolidations approach for more than one method. Of the textbook authors, seven gave primary focus to the complete equity method, four gave primary focus to the partial equity method, and only one gave primary focus to the cost method. Luehlfing noted that the consolidation worksheet entries will differ depending on the investment accounting entries recorded by the parent. To better understand the differences in resulting worksheet entries, Luehlfing suggested a conceptual teaching approach for showing the relationships between the parents' choices in accounting for its long-term investments. Once students can see the relationships between the methods, students would be better able to identify which method the parent is using, and then determine what worksheet entries are needed under each of the alternatives. Luehlfing also notes that only a minority of textbook authors choose to convert the parent's books and then have the same kind of consolidation worksheet entries for every consolidation rather than custom consolidation worksheet entries that depend on what the parent has recorded.

This paper recommends that the conversion approach be taken to standardize the type of consolidation worksheet entries, but to also provide greater emphasis on the consolidation concepts. Thus, the approach emphasizes the conceptual underpinnings and also addresses the necessity of dealing with the consolidation mechanics that are believed to decrease the level of complexity for an already-complex accounting issue.

\section{CONSOLIDATION COMPLEXITY}

The level of complexity for consolidations can be broken down into components that serve as building blocks, as many textbook authors do.

First, an assumption can be made that there are no intercompany transactions and then address these different scenarios: (1) A 100\% acquisition at the acquisition date; (2) A 100\% acquisition at the post-acquisition financial statement date; and (3) Less than $100 \%$ acquisition: at acquisition and post-acquisition. Next, the intercompany transactions can be addressed as separate worksheet entries.

However, complexity can be further reduced by standardizing the starting point for all consolidation worksheet entries by converting the parent's financials to the partial equity method rather than doing the conversion as part of the consolidation worksheet entries. The primary reason for this recommendation is to allow stronger reinforcement of the consolidation concepts since the entries would be the same if recorded on the parent's ledgers versus the consolidated worksheet. In addition, conversion to the partial equity method rather than the complete equity method allows greater emphasis on the primary consolidation concepts and a separate emphasis on the intercompany transactions which are grounded in different consolidation concepts.

\section{PARENTS' LONG-TERM INVESTMENT - ACCOUNTING ALTERNATIVES}

In order to understand the reason for the preference for converting to the partial equity method, the longterm investment accounting methods need to be summarized.

Table 1 summarizes the transactions recorded by the parent under each of the alternatives: 
Table 1

\begin{tabular}{|c|c|c|c|c|}
\hline & & & Effect on Parent's: & \\
\hline Method & $\begin{array}{c}\text { \# of U.S. } \\
\text { Textbook } \\
\text { Authors } \\
\text { Prefer }\end{array}$ & Transactions recorded & Investment Account & Income Statement \\
\hline Cost & 1 & - Dividends received from subsidiary & none & Increase \\
\hline \multirow[t]{3}{*}{ Partial Equity* } & \multirow[t]{3}{*}{4} & - Share of investee income/loss & Increase/decrease & Increase/decrease \\
\hline & & - Share of investee dividends & Decrease & none \\
\hline & & $\begin{array}{l}\text { - Amortization of allocated fair value }> \\
\text { book value** }\end{array}$ & Decrease & Decrease \\
\hline \multirow[t]{2}{*}{ Complete Equity } & \multirow[t]{2}{*}{7} & - Same as partial equity PLUS & See above & See above \\
\hline & & - Eliminate intercompany profits & Decrease & Decrease \\
\hline
\end{tabular}

*2 variations of the partial equity method either include or exclude the amortization of allocated fair value versus book value **assumes that overall, for the net assets acquired, the fair value exceeded book value

When all three components of the partial equity method noted in the above table are recorded by the parent after the acquisition of the subsidiary, the parent's books reflect in the totals, but not in detailed accounts, the same total amounts that should appear on the consolidated statements, assuming no intercompany transactions. Thus, students will see first-hand the relationships between the amounts from the converted parent's ledgers and the consolidated statements. The partial equity method adds the subsidiary's income to the parent's books as if the income was the parent's and treats the dividends received as a return of the investment, not income. The partial equity method also depreciates/amortizes the amounts of the fair values that differ from the book values associated with the subsidiary's net assets that are not reflected on the subsidiary's books, but should be from a consolidated perspective. Thus, from a consolidated perspective, the parent's books reflect in a "single-line" on the balance sheet (in the investment account) the appropriate valuation of the subsidiary's net assets; the parent's books reflect in a "single-line" on the income statement (in the equity in net income/loss of subsidiary account) the parent's share of the subsidiary's net income, appropriately adjusted for depreciation/amortization not recorded by the subsidiary from the revaluation of the subsidiary's net assets. As a result, students will see these relationships on their consolidation worksheet, assuming no intercompany transactions: (1) the parent's net income will equal consolidated net income; (2) the parent's statement of retained earnings will be the same as the consolidated one; and (3) the parent's equity account balances with equal consolidated equity account balances (except when there is a non-controlling interest). Seeing these relationships enforces the concept of merging the assets, liabilities, revenues and expenses of the entities being consolidated.

The consolidated worksheet adjustments for intercompany transactions are needed for different conceptual reasons. The profits recognized by the parent or the subsidiary, due to transactions between them, need to be eliminated from the consolidated statements. Therefore, giving those transactions separate treatment and highlighting the differences in the parent's and consolidated financials due to these transactions makes sense. The complete equity method would adjust the parent's books for the unrealized intercompany profits and mask the differences they cause between the parent's income and consolidated income.

\section{MATCHING THE MECHANICS TO THE CONCEPTUAL UNDERPINNINGS}

A tool that allows learning consolidation accounting complexities in stages, facilitates the mechanics of the consolidation process, and strengthens the understanding of the conceptual consolidation issues, is critical to student learning. An analysis of the parent's investment account at acquisition, that can be updated for post-acquisition activity and adapted when less than $100 \%$ of the subsidiary is acquired, can meet these objectives.

Below are facts associated with a consolidation that are depicted in the sample analysis of the investment tool: 
- $\quad$ Parent acquires $100 \%$ of subsidiary's stock for $\$ 1,000$

- $\quad$ Subsidiary's equity accounts on acquisition date include:

$\begin{array}{lll}\circ & \text { Common Stock } & \$ 100 \\ \circ & \text { Additional Paid-In Capital } & \$ 200 \\ \circ & \text { Retained Earnings } & \$ 300\end{array}$

- $\quad$ The only recorded asset of the subsidiary where fair value was greater than book value was for its Equipment which had a remaining life of ten years; at acquisition, the equipment's fair value exceed book value by $\$ 200$

- $\quad$ The subsidiary had $\$ 150$ in intangibles that the parent did include in the purchase price, but these intangibles were not reflected on the subsidiary's books;

- $\quad$ The subsidiary's post-acquisition net income in the year of the acquisition was $\$ 150$, and post-acquisition dividends declared by the subsidiary totaled $\$ 30$.

- $\quad$ Other than dividends, there were no intercompany transactions between the parent and the subsidiary.

The analysis of the investment account is demonstrated in Table 2.

Table 2

\begin{tabular}{|c|c|c|c|c|c|c|c|c|c|c|c|}
\hline & \multirow[b]{2}{*}{ Invest. } & \multirow[b]{2}{*}{$=$} & \multicolumn{5}{|c|}{ Sub's Book value of Equity } & \multicolumn{2}{|c|}{$\begin{array}{c}\text { Fair Value } \\
\text { Versus Book } \\
\text { Value }\end{array}$} & \multirow[b]{2}{*}{$\begin{array}{c}\text { Separable } \\
\text { Intangibles }\end{array}$} & \multirow[b]{2}{*}{ Goodwill } \\
\hline & & & $\mathrm{C} / \mathrm{S}$ & APIC & $\begin{array}{l}\text { Ret. } \\
\text { Earn. }\end{array}$ & $\begin{array}{c}\text { Net } \\
\text { Income }\end{array}$ & Div. & Equip. & $\begin{array}{l}\text { Accum. } \\
\text { Deprec. }\end{array}$ & & \\
\hline Acquis. Date & 1,000 & & 100 & 200 & 300 & 0 & 0 & 200 & 0 & 150 & 50 \\
\hline $\begin{array}{l}\text { Share of } \\
\text { sub's net } \\
\text { income }\end{array}$ & 150 & & & & & 150 & & & & & \\
\hline $\begin{array}{l}\text { Share of } \\
\text { Sub's } \\
\text { Dividends }\end{array}$ & (30) & & & & & & (30) & & & & \\
\hline $\begin{array}{l}\text { Amortization } \\
\text { of Fair Value } \\
\text { vs. Book } \\
\text { Value }\end{array}$ & (20) & & & & & & & & (20) & & \\
\hline $\begin{array}{l}\text { Post- } \\
\text { Acquisition } \\
\text { Year End }\end{array}$ & 1,100 & $=$ & 100 & 200 & 300 & 150 & (30) & 200 & (20) & 150 & 50 \\
\hline Reference & $\overline{\mathrm{a}}$ & & $\bar{b}$ & $\overline{\mathrm{C}}$ & $\overline{\mathrm{d}}$ & $\overline{\mathrm{e}}$ & $\bar{f}$ & $\overline{\mathrm{g}}$ & $\overline{\mathrm{H}}$ & $\overline{\mathrm{i}}$ & $\overline{\mathrm{j}}$ \\
\hline
\end{tabular}

The analysis can be prepared first at the acquisition date, along with consolidated statements. Notice that there are separate columns in the analysis for each of the accounts included in the components that comprise the investment account. The analysis can then also be used to compute the goodwill amount at acquisition (which is a plug after all other elements are considered). The complexity of consolidations can be minimized by first learning that only the balance sheet needs to be consolidated on the acquisition date; the parent's income statement does not need to have any adjustments, even if the acquisition is mid-year, since the parent can only recognize postacquisition income from the subsidiary.

Post acquisition, the investment account column in the analysis is updated assuming the parent adopts the partial equity method. The updates are also posted to the appropriate elements in the analysis. For example, the parent's share of the subsidiary's income increases the investment, but also increases the book value of the subsidiary's equity. 
Once the above analysis is completed, students should compare the Post-Acquisition Year-End investment account balance to the investment account balance on the parent's post-acquisition ledgers/financials. If the amounts are not the same, then the student knows that the parent's books will require adjustments prior to consolidating. Students should be able to identify which of the partial equity method entries are reflected on the parent's books by: (1) looking for the presence of Dividend Income on parent's books versus Equity in Net income of Subsidiary; and/or (2) determining if the Equity in Net Income of Subsidiary account includes (a) the parent's share of the subsidiary's net income; and/or (b) amortization of acquisition-date fair value versus book value of the subsidiary's net assets. Once students identify the entries needed to achieve the partial equity method, adjusted parent company financials under the partial equity method should be prepared so parent's investment account matches the amount shown on the analysis of the investment account. Students can either use a separate spreadsheet or add columns to show the adjusting entries \& adjusted parent's amounts on consolidated worksheet. Regardless of the approach selected, the adjusted parent amounts should be used on the consolidated worksheet.

The consolidation worksheet entries for the acquisition-date and the post-acquisition-date consolidation worksheet are derived directly from the analysis, facilitating the mechanics of generating worksheet entries. For example, the references noted below the post-acquisition year-end amounts on the analysis show exactly how the analysis of the investment maps directly into consolidation worksheet entry (Table 3).

Table 3: Consolidation Worksheet Entry Post-Acquisition

\begin{tabular}{|c|l|c|c|l|l|}
\hline Ref & \multicolumn{1}{|c|}{ Account } & DR & CR & Whose Account? & \multicolumn{1}{c|}{ Explanation } \\
\hline a & C/S & 100 & & Sub's & Zeros out sub's common stock \\
\hline b & APIC & 200 & & Sub's & Zeros out sub's APIC \\
\hline c & Ret. Earn. & 300 & & Sub's & Zeros out sub's Ret. Earn. \\
\hline d & Equity in NI of Sub & 150 & & Parent's & Removes parent's share of sub's NI from A/C \\
\hline e & Div. Declared & & 30 & Sub's & Zeros out sub's dividend declared \\
\hline f & Equip. & 200 & & Sub's & Increases sub's account from book to fair value \\
\hline g & Accum. Deprec. & & 20 & Sub's & Increases sub's account for deprec. recorded by parent \\
\hline h & Separable Intangibles & 150 & & New Parent A/C & $\begin{array}{l}\text { Creates new account for intangible acquired by parent } \\
\text { not recorded in separate account by sub }\end{array}$ \\
\hline i & Goodwill & 50 & & New Parent A/C & $\begin{array}{l}\text { Creates new account for goodwill paid by parent not } \\
\text { recorded in separate account by sub }\end{array}$ \\
\hline j & Investment & & 1,100 & Parent's & Zeros out parent's investment account \\
\hline
\end{tabular}

The beauty of first converting the parents' books to the partial equity method is that the above consolidation worksheet entry will be the same no matter what method the parent was using during the period prior to adjustment of the long-term investment. Standardization of the worksheet entry decreases the complexity of consolidations accounting for students. In addition, an explanation of each debit and credit explains the effect of each entry and reinforces how the consolidations concepts are implemented.

In addition to the above worksheet entry derived from the analysis of the investment account, an entry is needed to reclassify the depreciation/amortization recorded by the parent in its Equity in Subsidiary's Net Income/Loss account into the appropriate subsidiary account(s) (Table 4).

Table 4: Consolidation Amortization Reclassification Worksheet Entry, Post Acquisition

\begin{tabular}{|c|c|c|l|l|}
\hline Account & DR & CR & \multicolumn{1}{|c|}{ Whose A/C? } & \multicolumn{1}{c|}{ Explanation } \\
\hline Depreciation Expense & 20 & & Sub's & Adds deprec. of FV vs BV to sub's deprec. acct. \\
\hline Equity in NI of Sub & & 20 & Parent's & Removes FV vs BV amortized under equity method \\
\hline
\end{tabular}

Notice that there are no intercompany transactions in this example; however, even if there were, students can first assume that there are no intercompany transactions and use the above approach to worksheet entries. Under that assumption, students will still be able to see the relationships between the parent and consolidated statements amounts prior to developing and posting worksheet entries to the consolidated worksheet pertaining to intercompany transactions. 


\section{PARTIAL EQUITY METHOD AND CONSOLIDATIONS CONCEPTS}

Assuming no intercompany transactions and use of the partial equity method, then consolidated equity should equal the parent's equity (assuming no non-controlling interest). As a result, the worksheet entries are merely replacing the parent's investment account with the subsidiary's assets and liabilities. The subsidiary's equity accounts on its balance sheet are not needed, and thus, are eliminated with the worksheet entries. The subsidiary's amounts on the consolidation worksheet represent the book values and the worksheet entries adjust the book values to their acquisition-date unamortized fair values. The worksheet entries also extract amounts that are buried in the investment account, including any separable intangibles and goodwill, that were paid for by the parent but are not separately identified on the subsidiary's books.

When there are no intercompany transactions and the parent uses the partial equity method, consolidated net income equals the parent's net income. While the net income totals are the same, the individual accounts need to be adjusted. The worksheet entries replace the subsidiary's net income included in the parent's Equity in Subsidiary's net income account with the detailed accounts from the subsidiary's income statement (revenue, expense, gain, loss). Thus, the netted figure (net income) is replaced with the gross revenue and expense accounts, as well as any gains or losses.

Therefore, the parent's partial equity method financial statements are conceptually consistent with the consolidated totals (because they are the same), but not conceptually consistent with the details needed for the consolidated statements. For example, the subsidiary's liabilities are buried in the parent's investment account rather than being added to the parent's liability accounts. The consolidation worksheet resolves this type of problem. As a result, the worksheet entries are merely trying to achieve a different level of detail, but some of the same totals, for the parent and consolidated statements. If the partial equity method is not being used, the parent's and consolidated net income and equity amounts will not match. As a result, the worksheet entries will be achieving both the conversion to the partial equity method and creating the desired detail in the consolidated statements.

Thus, the worksheet entries when the parent uses the partial equity method emphasize these multiple roles of the consolidation worksheet:

1. Replaces parent's investment with the assets and liabilities of the subsidiary

2. Eliminates the subsidiary's equity accounts and post-acquisition dividends

3. Revalues the subsidiary's recorded book values to unamortized fair values from the acquisition date

4. Sets up separate accounts for assets acquired by the parent that are not specifically listed on the subsidiary's books, including separable intangibles and goodwill

5. Replaces the Equity in Net Income of Subsidiary account with the subsidiary's individual income statement accounts

6. Adjusts the subsidiary's depreciation/amortization for added amounts recorded by the parent pertaining to the acquisition-date fair values versus book values.

\section{EFFECT OF NON-CONTROLLING INTERESTS}

The analysis of the investment account can be readily adapted when the parent does not acquire $100 \%$ of the subsidiary's common stock. A column is merely inserted to the left of the parent's investment account and is updated post acquisition under the same assumption as the investment account -- assuming the partial equity method. To show how this would be implemented, merely assume that the parent acquired only $90 \%$ of the subsidiary's stock, but use all of the same facts from the prior example. The resulting analysis of the investment account is reflected in Table 5, with the added column for non-controlling interest highlighted: 
Table 5: Analysis of Investment Account - Includes Non-Controlling Interest

\begin{tabular}{|c|c|c|c|c|c|c|c|c|c|c|c|c|}
\hline & & \multicolumn{5}{|c|}{ Sub's Book value of Equity } & \multicolumn{2}{|c|}{$\begin{array}{c}\text { Fair Value vs. } \\
\text { Book Value }\end{array}$} & \\
\hline & $\begin{array}{c}\text { of } \\
\text { Sub. }\end{array}$ & Invest. & $=$ & $\mathbf{C} / \mathrm{S}$ & APIC & $\begin{array}{l}\text { Ret. } \\
\text { Earn. }\end{array}$ & $\begin{array}{l}\text { Net } \\
\text { Inc. }\end{array}$ & Div. & Equip. & $\begin{array}{l}\text { Accum. } \\
\text { Deprec. }\end{array}$ & $\begin{array}{c}\text { Separable } \\
\text { Intangibles }\end{array}$ & Goodwill \\
\hline Acquis. Date & 100 & 900 & & 100 & 200 & 300 & 0 & 0 & 200 & 0 & 150 & 50 \\
\hline $\begin{array}{l}\text { Share of sub's } \\
\text { net income }\end{array}$ & 15 & 135 & & & & & 150 & & & & & \\
\hline $\begin{array}{l}\text { Share of Sub's } \\
\text { Dividends }\end{array}$ & (3) & (27) & & & & & & (30) & & & & \\
\hline 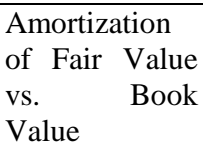 & (2) & (18) & & & & & & & & (20) & & \\
\hline $\begin{array}{l}\text { Post- } \\
\text { Acquisition } \\
\text { Year End } \\
\end{array}$ & 110 & 990 & $=$ & 100 & 200 & 300 & 150 & $(30)$ & 200 & $(20)$ & 150 & 50 \\
\hline Reference & $\mathrm{k}$ & $\bar{a}$ & & $\mathrm{~b}$ & $\mathrm{c}$ & $\bar{d}$ & $\overline{\mathrm{e}}$ & $\mathrm{f}$ & $\mathrm{g}$ & $\mathrm{H}$ & $\overline{\mathrm{i}}$ & $\bar{j}$ \\
\hline
\end{tabular}

One primary difference resulting from having a non-controlling interest is the post-acquisition amounts from the partial equity method are now split between the parent and the non-controlling interest in the net asset (balance sheet) account. In addition, the worksheet entries from the "Net.Inc." column of the analysis must now be split between the parent's Equity in Net Income of Subsidiary Account and the Non-Controlling Interest in Subsidiary's Net Income account. Both of the non-controlling accounts are now created with the consolidation worksheet entry created from this analysis. Many textbooks create those accounts as separate worksheet entries or by creating separate columns in the consolidated worksheet, which further complicates the consolidation process.

Table 6 reflects consolidation worksheet entry resulting from the above analysis.

Table 6: Consolidation Worksheet Entry Post-Acquisition - Includes Non-Controlling Interest

\begin{tabular}{|c|l|c|c|l|l|}
\hline Ref & & DR & CR & Whose Account? & Explanation \\
\hline b & C/S & 100 & & Sub's & Zeros out sub's common stock \\
\hline c & APIC & 200 & & Sub's & Zeros out sub's APIC \\
\hline d & Ret. Earn. & 300 & & Sub's & Zeros out sub's Ret. Earn. \\
\hline e1 & Equity in NI of Sub & $\mathbf{1 3 5}$ & & Parent's & Removes parent's share of sub's NI from A/C \\
\hline e2 & NCI in NI of Sub & $\mathbf{1 5}$ & & New Consol. A/C & $\begin{array}{l}\text { Creates new account since 100\% of Rev \& Exp of } \\
\text { sub on consolidated financials }\end{array}$ \\
\hline F & Div. Declared & & 30 & Sub's & Zeros out sub's dividend declared \\
\hline g & Equip. & 200 & & Sub's & Increases sub's account from book to fair value \\
\hline h & Accum. Deprec. & & 20 & Sub's & $\begin{array}{l}\text { Increases sub's account for deprec. recorded by } \\
\text { parent }\end{array}$ \\
\hline i & Separable Intangibles & 150 & & New Consol. A/C & $\begin{array}{l}\text { Creates new account for intangible acquired by } \\
\text { parent not recorded in separate account by sub }\end{array}$ \\
\hline j & Goodwill & 50 & & New Consol. A/C & $\begin{array}{l}\text { Creates new account for goodwill paid by parent not } \\
\text { recorded in separate account by sub }\end{array}$ \\
\hline a & Investment & & $\mathbf{9 9 0}$ & Parent's & Zeros out parent's investment account \\
\hline k & NCI-Net Assets of Sub. & & $\mathbf{1 1 0}$ & New Consol. A/C & $\begin{array}{l}\text { Creates new account since 100\% assets \& liab. of } \\
\text { sub. on consolidated financials }\end{array}$ \\
\hline
\end{tabular}

(NOTE: Bolded parts are different due to having a non-controlling interest) 
Now both the Equity in Subsidiary's Net Income and the Non-Controlling Interest in Subsidiary's Net Income need to be adjusted for the missing depreciation/amortization associated with the fair value versus book value amounts not reflected on the subsidiary's books. Table 7 achieves that result.

Table 7: Consolidation Amortization Reclassification Worksheet Entry, Post Acquisition - Includes Non-Controlling Interest

\begin{tabular}{|l|c|c|l|l|}
\hline Depreciation Expense & 20 & & Sub's & $\begin{array}{l}\text { Puts depreciation recorded by parent for fair value vs. } \\
\text { book value in sub's depreciation account }\end{array}$ \\
\hline Equity in NI of Sub. & & 18 & Parent's & $\begin{array}{l}\text { Removes parent's share of depreciation of fair value vs. } \\
\text { book value from this account }\end{array}$ \\
\hline NCI - Net inc. of Sub. & & 2 & New Consol. A/C & $\begin{array}{l}\text { Takes NCI share of deprec. out of NCI share of sub's net } \\
\text { income account }\end{array}$ \\
\hline
\end{tabular}

\section{FLEXIBILITY OF ANALYSIS OF INVESTMENT ACCOUNT}

A number of consolidations issues have not yet been addressed, including what can be capitalized in the investment account and goodwill impairment. The analysis of the investment account adds greater clarity regarding the ultimate resolution of these types of items on the consolidated financial statements. For example, goodwill impairment would be inserted on the analysis of the investment as an additional row and considered part of the partial equity method entries, reducing the amounts in the investment and goodwill columns.

The analysis can reflect the effect of correctly or incorrectly capitalizing costs in the investment account on the acquisition date, showing that those amounts would be buried in goodwill on the consolidated financial statements. The analysis is also a great tool for comparing the non-GAAP valuation approaches to the GAAP methods, as suggested by Nurnberg and Sweeney (2007).

The analysis, however, is not intended to address the worksheet entries needed as a result of intercompany transactions. Intercompany inventory, fixed assets, and bond transactions are significantly different from the activity reflected on the analysis of the investment account. Intercompany transactions warrant being addressed separately, using an approach similar to that recommended by Keister (1967). Students can write the entries recorded by the parent and the subsidiary pertaining to the intercompany transactions and evaluate them from a consolidated perspective in order to determine the appropriate worksheet entry. Students can also compare the parent's net income under the partial equity method to the consolidated net income after including worksheet adjustments for intercompany transactions. Requiring students to reconcile the parent's partial equity method net income to the consolidated net income emphasizes the fact that only unrealized gains/losses/profits from intercompany transactions are causing this difference. Once again, the conceptual consolidation underpinnings of intercompany transactions can be given a greater emphasis by converting to the partial equity rather the complete equity method.

\section{CONCLUSION}

Consolidations accounting is challenging to teach, and as a result, is even more challenging for students to learn. Approaches that can reinforce the conceptual understanding, as well as facilitate the mechanics of the consolidations process, should be encouraged. The approach of converting the parent's ledgers to the partial equity method emphasizes the relationships between the parent's financial statements and the desired consolidated financial statements. Utilization of the analysis of the investment account facilitates the mechanics of the consolidation process, but also provides a mechanism for identifying which investment accounting method the parent is using and the resulting conversion entries needed, if any. At the same time, the analysis of the investment account provides a vehicle for conducting "what if" analysis for other complexities of the consolidation process. 


\section{AUTHOR INFORMATION}

Elizabeth A. Murphy, PhD, MBA, CPA is an Associate Professor in the School of Accountancy and Management Information Systems of DePaul University, Chicago, Illinois. Her primary teaching interests are financial, governmental, and not-for-profit accounting. She has earned multiple teaching awards from DePaul University, the Illinois CPA Society (2005 Outstanding Educator Award), and other organizations.

Mark A. McCarthy, JD, MAS, CPA, CMA is an Assistant Professor in the School of Accountancy and Management Information Systems of DePaul University, Chicago, Illinois. His primary teaching interests are managerial accounting and taxation. He also serves as the Director of DePaul's C.P.A. Review program.

\section{REFERENCES}

1. American Institute of Certified Public Accountants (AICPA). Accounting Research Bulletin No. 51, "Consolidated Financial Statements.". AICPA, New York, August, 1959.

2. Chasteen, L. G. (2005). Teaching variable interest entities under FIN 46: Untangling risks, expected losses, and expected residual returns. Journal of Accounting Education, 23 (1), 47-66.

3. James, M. L. (2008). Accounting majors' ability to identify financial reporting errors and omission and the convergence between U.S. GAAP and International Financial Reporting Standards. Allied Academies International Conference: Proceedings of the Academy of Accounting \& Financial Studies , 13 (2), 14-18.

4. Keister, O. R. (1967). Consolidations and Intercompany Bond Holdings. Accounting Review , 42 (2), 37576.

5. Kimmel, D. L. (1976). Consolidation Models at Acquisition - Purchase and Pooling of Interest Methods. Accounting Review , 51 (3), 629-32.

6. Luehlfing, M. S. (1995). Methods of consolidation in current accounting textbooks. Journal of Accounting Education, 13 (3), 349-65.

7. Numberg, H., \& Sweeney, J. (2007). Understanding Accounting for Business Combinations: An Instructional Resource. Issues in Accounting Education , 22 (2), 255-84.

8. O'Connor, W., Rapaccioli, D., \& Williams, P. A. (1996). Internationalizing the Advanced Accounting Course. Issues in Accounting Education, 11 (2), 315-35.

9. $\quad$ Perry, K. W. (1963). Intercompany profits and ARB 51. Accounting Review, 38 (3), 626-28.

10. Scofield, B. W. (1996). Alcoa: Toward understanding minority interest. Journal of Accounting Education, 14 (4), 579-606.

11. Spiller Jr., E. A. (1962). Teaching consolidated income statements - a new approach. Accounting Review, 37 (2), 336-42. 


\section{NOTES}

